\title{
IDENTIFIKASI SPESIES BEGONIA LITOFIT DI KABUPATEN BENGKAYANG KALIMANTAN BARAT
}

(Identification of Litophyte Begonia Species in Bengkayang District West Kalimantan)

\author{
Hasri Nurfadillah Rahyu Ningsih, Siti Masitoh Kartikawati, Muflihati \\ Fakultas Kehutanan Universitas Tanjungpura Pontianak, Indonesia \\ Email: hasrinurfadillah@gmail.com
}

\begin{abstract}
Begonia is a plant from the flowering tribe of Begoniaceae which still has not revealed much diversity and potential. Begonia recorded in Borneo includes Brunei 21 species, Kalimantan 5 species, Sabah 82 species and Sarawak 96 species. Generally begonias are found in calcareous rocks also in sandy and granite rocks. Begonia can also be found around waterfalls or small streams. Begonia grows from lowlands to hilly forests. This study aims to identify the Begonia genus in Bengkayang Districts. This study uses an exploratory method by exploring the entire area from corner to corner by using the length of the observation path from the river bank to the height level representing ecosystems and vegetation on the location studied. Result of research there are species of Begonia serianensis C. W. Lin \& C.-I Peng., Begonia promethea Ridl. Begonia calcarea Ridl., Begonia bawangensis Hughes. sp. nov. (in prep.) dan Begonia magnicarpa C.W.Lin \& C. I Peng.
\end{abstract}

Keywords: Bengkayang District, Identification, Litophyte Begonia.

\section{Abstrak}

Begonia merupakan tumbuhan berbunga Begoniaceae yang masih belum banyak terungkap keanekaragaman dan potensinya. Begonia yang terdata di Borneo meliputi Brunei 21 spesies, Kalimantan 5 spesies, Sabah 82 spesies dan Sarawak 96 spesies. Umumnya begonia terdapat pada batuan berkapur juga di batuan berpasir dan granit. Begonia juga dapat ditemukan di sekitar air terjun atau aliran air kecil. Begonia tumbuh dari dataran rendah hingga hutan perbukitan. Penelitian ini bertujuan untuk mengidentifikasi spesies dari genus Begonia yang ada di Kabupaten Bengkayang. Penelitian ini menggunakan metode eksplorasi dengan menjelajah seluruh kawasan dari sudut ke sudut dengan mengunakan panjang jalur pengamatan baik dari tepi sungai sampai pada tingkat ketinggian yang dapat mewakili ekosistem maupun vegetasi pada lokasi yang diteliti. Hasil penelitian terdapat lima spesies, yaitu Begonia serianensis $C$. W. Lin \& C.-I Peng., Begonia promethea Ridl. Begonia calcarea Ridl., Begonia bawangensis Hughes. sp. nov. (in prep.) dan Begonia magnicarpa C.W.Lin \& C. I Peng.

Kata kunci: Begonia litofit, Identifikasi, Kabupaten Bengkayang. 


\section{PENDAHULUAN}

Begonia merupakan tumbuhan berbunga, terna yang menjalar dan termasuk famili Begoniaceae. Spesies Begonia yang berjumlah lebih kurang 1500 spesies tersebar luas di Afrika tropis dan subtropis, Amerika, Asia dan Kepulauan Pasifik (Hughes 2008). Julia dan Kiew (2014) memperkirakan terdapat 600 spesies Begonia di Borneo, 194 diantaranya telah dideskripsikan dan diberi nama secara Binomial Nomenclature, tetapi masih banyak lagi Begonia yang didapat dan belum memiliki deskripsi maupun nama ilmiah. Pada tahun 2015, terdata 204 spesies Begonia yang teridentifikasi yaitu meliputi Brunei 21 spesies, Sabah 82 spesies, Sarawak 96 spesies, dan Kalimantan 5 spesies (Kiew et al. 2015).

Karakteristik Begonia dicirikan dengan daun berbentuk asimetris, oval, menjari seperti daun palem, terompet atau berumbai-rumbai, tergantung dari spesiesnya. Sebagian besar di Borneo bentuk daunnya bulat hingga memanjang. Letak daun tersebar dengan warna dan corak yang beragam. Daunnya ada yang tipis, setengah tebal hingga tebal. Batang mengandung air, tumbuh tegak, merambat serta memiliki bunga jantan dan bunga betina (Kiew et al. 2015).

Begonia tumbuh dari dataran rendah hingga hutan perbukitan. Habitat Begonia sebagian besar berada di teresterial namun ada juga hidup di litofit. Tipe teresterial adalah tempat tumbuh yang ada di daratan atau tanah, sedangkan litofit ialah tempat tumbuh pada substrat bebatuan. Menurut Kiew
(2005) Begonia menyukai habitat batuan berkapur, batuan berpasir dan granit. Tumbuhan ini juga dapat ditemukan di sekitar air terjun atau aliran air kecil .

Gunung bawang memiliki keanekaragaman hayati yang tinggi seperti Keruing (Dipterocarpus coriaceus), Meranti (Shorea spp), Cempedak hutan (Artocarpus spp), dan jenis-jenis tumbuhan hias seperti anggrek dan keladi hias (Marega, 2016). Keberadaan spesies Begonia di Borneo yang tumbuh pada batuan sangatlah beragam dan status endemik sangat tinggi. Begonia merupakan indikator suatu ekologi yang baik. Oleh karena itu, identifikasi spesies Begonia litofit yang ada di Kabupaten Bengkayang perlu dilakukan.

\section{METODE PENELITIAN}

Penelitian dilaksanakan di Kabupaten Bengkayang Batuan Kapur Kecamatan Siding, Riam Berawan't Kecamatan Seluas, Gunung Bawang Kecamatan Sungai Betung dan Gunung Damus di dalam kawasan CA Niut Dusun Umbo Kecamatan Seluas dengan waktu pelaksanaan penelitian 21 Januari - 18 Februri 2019 di lapangan.

Alat-alat yang digunakan antara lain adalah kamera, GPS, tally sheet, peta lokasi, dan buku referensi. Objek penelitian ini adalah spesies Begonia yang ada di Batuan Kapur Kabupaten Bengkayang.

Metode penelitian menggunakan metode eksplorasi dengan menjelajah seluruh kawasan dari sudut ke sudut dengan mengunakan panjang jalur pengamatan baik dari tepi sungai sampai pada tingkat ketinggian yang dapat 
mewakili ekosistem maupun vegetasi pada lokasi yang diteliti (Rugayah 2004). Identifikasi spesies berdasarkan pada buku karangan Kiew et al. tahun 2005 dan berbagai jurnal terkait.

Analisis data yang digunakan adalah analisis kualitatif. Analisis dilakukan dengan cara mendeskripsikan ciri-ciri morfologi (generatif maupun vegetatif) secara detail pada semua jenis terna yang ditemukan di setiap jalur penelitian.

\section{HASIL DAN PEMBAHASAN}

Hasil pengamatan di lapangan ditemukan lima spesies Begonia litofit (Tabel 1).

\section{Tabel 1. Spesies Begonia (Species of Begonia)}

\begin{tabular}{clll}
\hline No. & \multicolumn{1}{c}{ Nama Spesies } & Habitat & \multicolumn{1}{c}{ Lokasi } \\
\hline 1 & Begonia serianensis C. W. Lin \& C.-I Peng. & Litofit & Batuan Kapur \\
2 & Begonia promethea Ridl. & Litofit & Riam Berawat'n \\
3 & Begonia calcarea Ridl. & Teresterial \& Litofit & Umbo \\
4 & Begonia bawangensis Hughes. sp. nov. (in prep.) & Litofit & Gn. Bawang \\
5 & Begonia magnicarpa C.W.Lin \& C. I Peng. & Litofit & Air Terjun Tikalong \\
\hline
\end{tabular}

1. Begonia serianensis C. W. Lin \& C.-I Peng.

B. serianensis ditemukan pada batuan kapur (litofit). Whitten et al. 1987 dan Vermeulen dan Whitten 1999 dalam Achmad A (2011) mengungkapkan karakteristik batuan kapur berupa bukit- bukit yang tingginya \pm 300 meter, dinding bertebing tegak terpisah-pisah dengan sisi yang terjal-terjal permukaan kasar, gua-gua dan biasanya membentuk aliran sungai di bawah tanah serta mata air. Kondisi tersebut dapat dilihat pada Gambar 1.

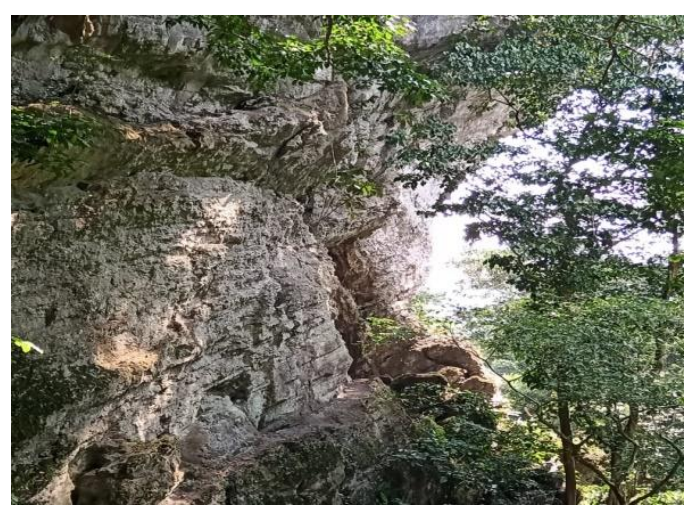

Gambar 1. Batuan Kapur (Limestone)

Batang zig zag berwarna hijau kecoklatan dan tertutupi oleh bulu-bulu halus berwarna putih. Menurut Lin \& Peng (2017) batang Begonia dengan warna hijau hingga kemerahan, merayap, panjang 4-10 cm. Daun membundar telur (ovate), 5-6 x 4-5 cm, permukaan atas daun berwarna hijau mengilap dengan tekstur licin, permukaan bawah daun berwarna hijau keputihan, daun muda berwarna hijau kecoklatan. Menurut Lin \& Peng (2017) daunnya membentuk roset, daun yang peltate dengan ukuran 7-13 x 7-13,5 cm, berwarna hijau kehijau pucat. Bunga Begonia ini memiliki dua kelamin yaitu bunga jantan dan betina yang ukurannya kecil berwarna putih hingga merah 
muda, bunga jantan memiliki empat buah tepal dan bunga betina memiliki 5 tepal. Menurut Lin \& Peng (2017) bunga jantan memiliki 4 tepal berwarna merah muda pucat hingga putih, bunga betina memiliki 5 tepal berwarna merah muda keputihan. Buah berbentuk bulat, memiliki tiga sayap dan berwarna merah muda. Menurut Lin \& Peng (2017) buah berwarna kemerahan hingga kuning pucat atau hijau, memiliki 3 sayap yang tidak sama rata, berbentuk segitiga hingga membentuk bulan sabit yang membulat di ujung menyempit di pangkal.

Ekologi B. serianensis berada pada tebing Batuan Kapur di Desa Siding
Kecamatan Siding Kabupaten Bengkayang Kalimantan Barat (Gambar 1). Ditepi hutan dengan ketinggian $88 \mathrm{~m}$ dpl. Lin \& Peng (2017) menerangkan bahwa $B$. serianensis merupakan spesies baru yang ditemukan di Sarawak, Kalimantan Barat Daya.

B. serianensis juga hampir sama morfologinya dengan $B$. andersonii Kiew \& S. Julia (Kiew dan Julia, 2007). Salah satu morfologinya yang hampir sama yaitu pada daunnya, daun $B$. serianensis berbentuk membundar telur (ovate) dan bentuk daun yang peltate. Sedangkan $B$. andersonii berbentuk membundar namun pada tidak peltate.

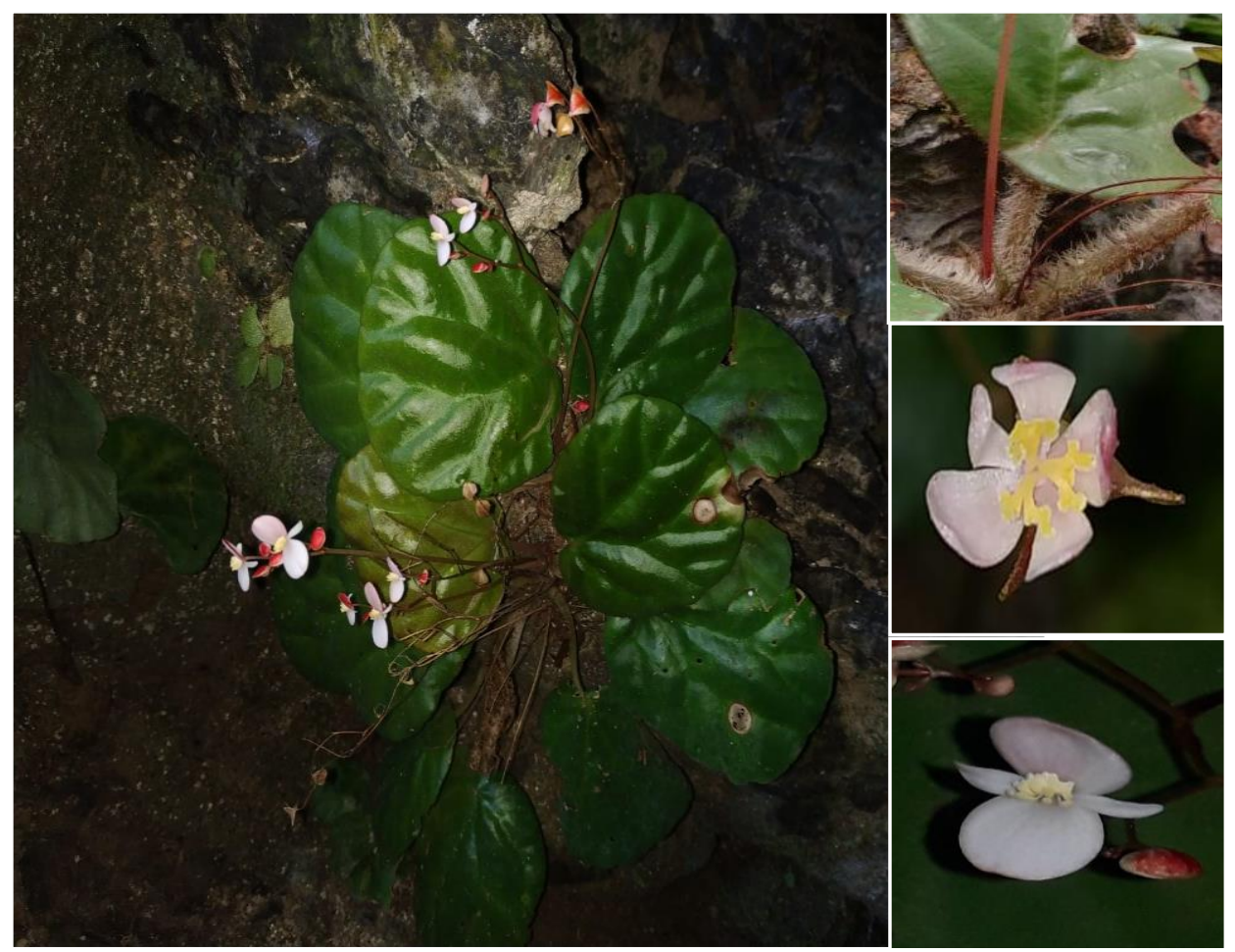

Gambar 2. B. serianensis Lin \& Peng a. Habitat. b. Bunga jantan. c. Bunga betina d. Batang (B. serianensis Lin \& Peng a. Habitat. b. Male flower $\boldsymbol{c}$. Female flower d. stem).

\section{Begonia promethea Ridl.}

B. promethea ditemukan di batuan pasir, tebing air terjun Riam Berawat'n (litofit). Menurut Nurwidyanto et al.
(2006) batuan pasir memiliki kenampakan fisik yang dapat dibedakan dengan batuan lainnya seperti struktur, komposisi, dan tekstur. Batuan ini 
memiliki batu-batu yang renggang tapi padat yang terdiri dari fragmen-fragmen yang menyatu dan mengeras. Dalam ruang batuan ini selalu terisi air tawar atau air asin. Kondisi tersebut dapat dilihat pada Gambar 3.

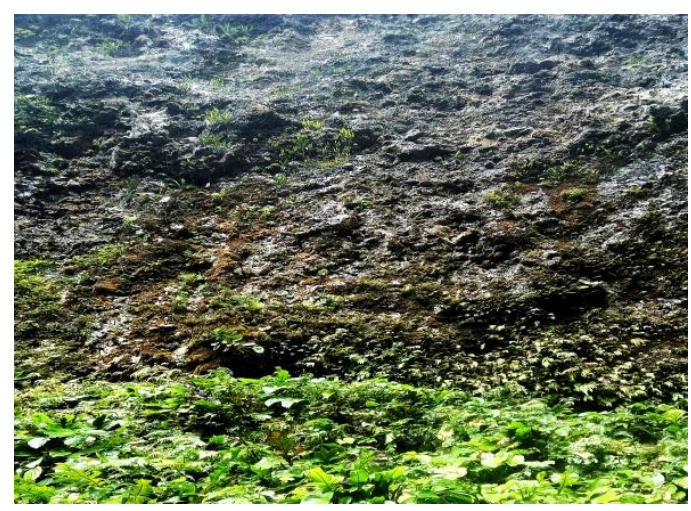

Gambar 3. Batuan Pasir (Standstone Rocks)

Batang yang berwarna merah kecoklatan yang diselimuti rambut halus berwarna merah. Menurut Kiew et al. (2018) umumnya panjang batang 2-10 $\mathrm{cm}$ yang menempel pada permukaan batu. Batang setebal $0.5 \mathrm{~cm}$, merah kecoklatan, dan beruas $0.8-1.8 \mathrm{~cm}$. Memiliki rambut halus berwarna putih atau kecoklatan. Pertumbuhan daun 2-3 helai. Tangkai daun merah atau coklat kemerahan, berambut halus dan bentuk daun yang membulat. Daun $B$. promethea berbentuk membundar telur (ovate) dengan diameter $5-15 \mathrm{~cm}$, warna dasar permukaan atas daun berwarna hijau mengkilap dengan tulang daun jelas dan berwarna kecokelatan dan bertekstur halus, permukaan bawah daun berwarna hijau dan pertulangan daun berwarna kecoklatan, permukaan atas dan bawah daun ditumbuhi rambut halus tipis berwarna merah keputihan. Menurut Kiew et al. (2018) daunnya berbentuk bulat telur hingga orbicular dengan ukuran 8,5-17,5 x 8,5-17 cm, permukaan atas daun berwarna hijau gelap dengan garis berwarna keunguunguan embentuk pertulangan daun, permukaan bawah daun memiliki bulu berwarna kemerahan. Bunga jantan memiliki dua tepal berwarna putih kemerahan, bunga betina memiliki lima tepal berwarna putih kemerahan. Menurut Kiew et al. (2018) Bunga jantan memiliki dua tepal, bagian dalam berwarna putih kemerah mudaan, bagian luar berwarna merah muda. Bunga betina memiliki lima tepal berwarna putih kemerah mudaan. Buah berbentuk bulat, memiliki 3 sayap dan berwarna putih kemerahan. Menurut Kiew et al. (2018) Panjang kapsul buah 12-15 x 12-19 mm, dengan sayap yang sama membulat. Ekologinya $B$. promethea berada pada hutan dataran rendah pada ketinggian $158 \mathrm{~m}$ dpl, tumbuh di tebing, batuan pasir basah, teduh, dan sering terkena semprotan air seperti air terjun. 


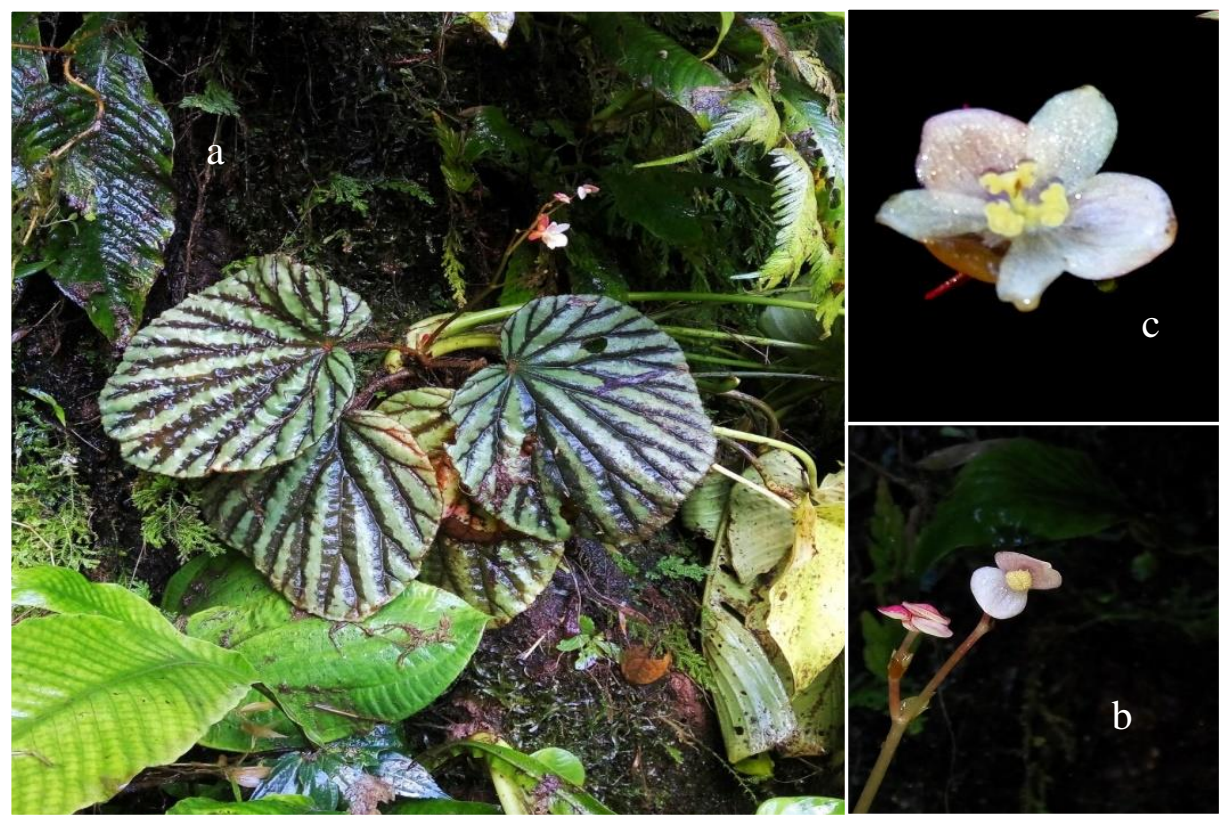

Gambar 4. B. promethea a. Habitat. b. Bunga jantan. c. Bunga Betina. (B. promethea a. Habitat. b. Male flower. c. Female Flower).

\section{Begonia calcarea Ridl.}

Begonia calcarea Ridl. ditemukan di batuan sekitar aliran sungai kecil.
Kondisi hutan tersebut dapat dilihat pada Gambar 5.

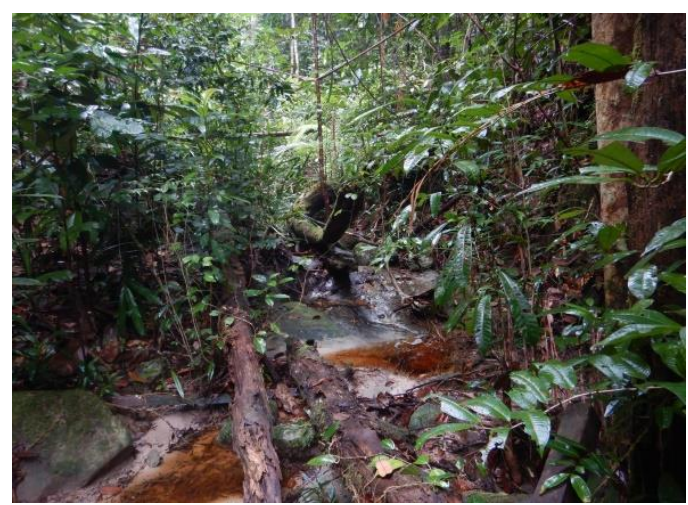

Gambar 5. Aliran Air Kecil (small river)

Batang dengan tinggi 9-19 $\mathrm{cm}$ berwarna merah kecoklatan dan memiliki rambut halus yang lebat berwarna merah. Menurut Kiew et al. (2015) umumnya batang yang ditumbuhi rambut halus. Daun yang asimetris berbentuk bundar telur terbalik (obovate) dengan panjang 5-6 $\mathrm{cm}$ dan lebar 3-8 cm, permukaan atas daun berwarna hijau, tekstur licin dan ditumbuhi rambut halus secara menyebar, permukaan bawah daun berwarna hijau, ditumbuhi rambut halus dan tepi daun bergerigi. Menurut Kiew et al. (2015) daunnya berwarna hijau pucat, $15 \times 10 \mathrm{~cm}$ dan rambut halus yang tumbuh jarang. Bunga jantan memiliki 4 tepal dan bunga betina memiliki 5 tepal berwarna jingga kemerahan. Kiew et al. (2015) bunga jantan memiliki empat 
tepal, 7-11 x 5-9 mm. Buah berbentuk bulat, memiliki 3 sayap dan berwarna jingga kemerahan. Kiew et al. (2015) buah memiliki tiga sayap, 5-7 $\mathrm{mm}$ lebarnya yang membulat. Ekologinya $B$. calcarea biasanya tumbuh dekat dengan air.

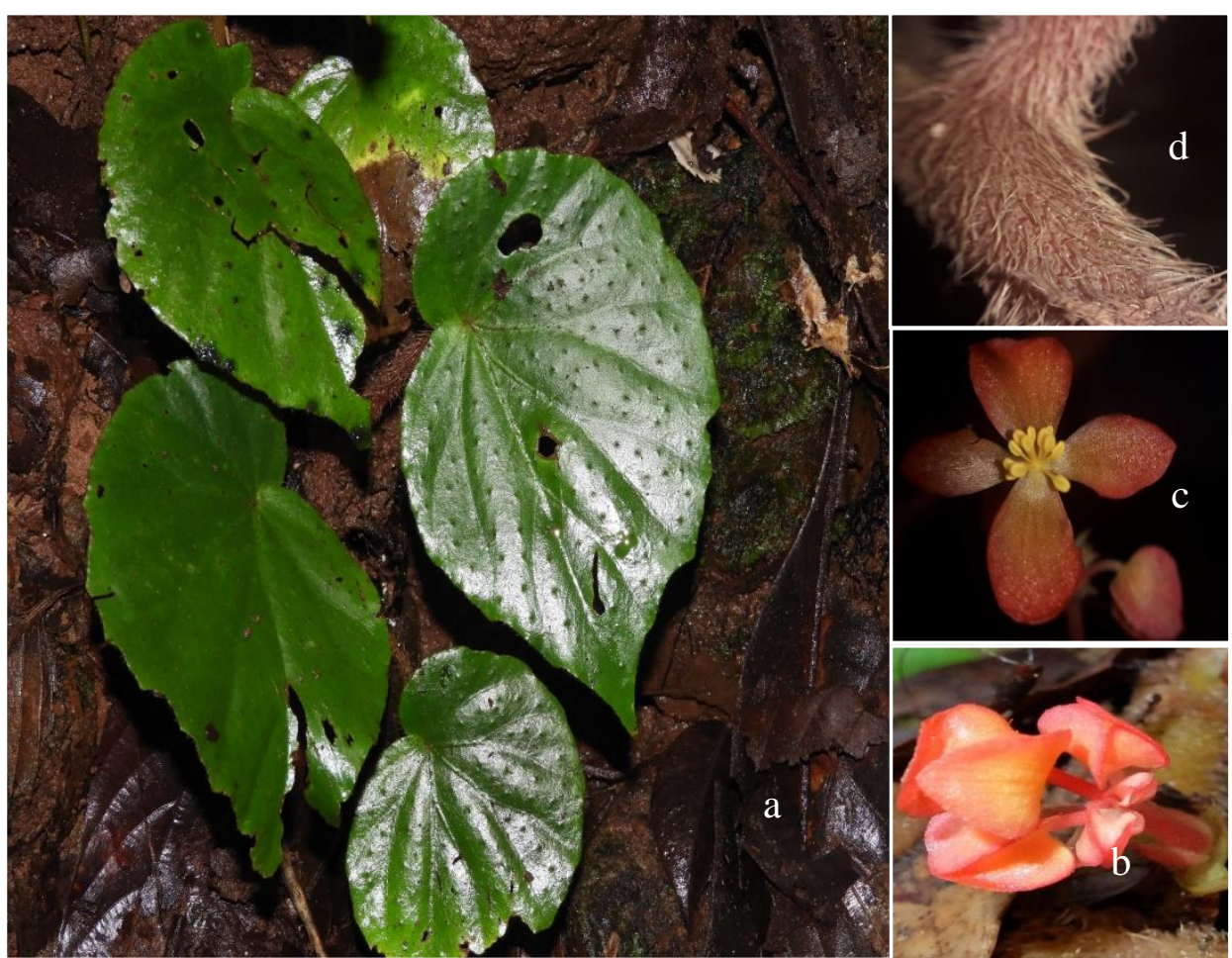

Gambar 6. B. calcarea Ridl. a. Habitat. b \& c Bunga jantan. d. Stem. (B. calcarea Ridl. a. Habitat. . b \& c Male Flower. $d$. Stem).

4. Begonia bawangensis Hughes. sp. ditemukan di sekitar air terjun atau aliran nov. (in prep.)

Menurut Kiew (2005) Begonia menyukai habitat batuan berkapur, batuan berpasir dan granit. Juga dapat air kecil . Begonia tumbuh dari dataran rendah hingga hutan perbukitan seperti yang ditemukan di Kabupaten Bengkayang (Gambar 7).

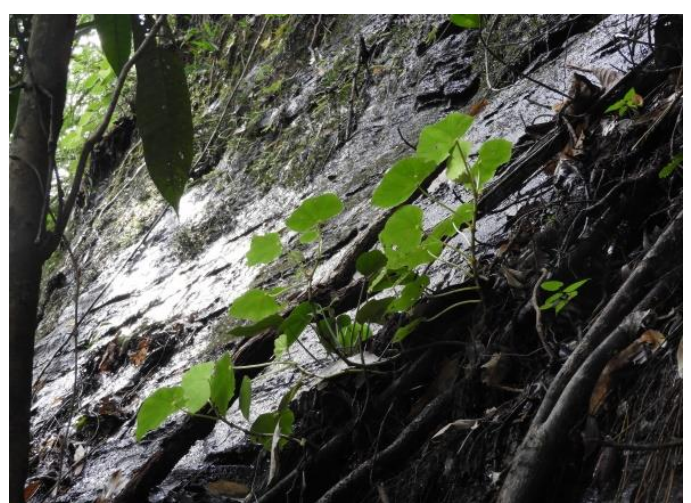

Gambar 7. Kondisi Hutan pada Ketinggian 600 - $800 \mathrm{M}$ Dpl (forest condition at altitude 600-800 m asl)

Berupa terna yang tumbuh pada bebatuan. Batang licin dan berwarna hijau. Daun yang membundar telur terbalik (obovate) dan teksturnya licin (tidak berbulu) dengan panjang 4-8 $\mathrm{cm}$ dan lebar 3-7 cm, permukaan atas daun 
berwarna hijau mengilap, permukaan bawah daun berwarna hijau dan tepi daun bergerigi. Bunga jantan berwarna putih dan memiliki 4 tepal sedangkan bunga betina berwarna putih, memiliki 5 tepal. Buah berbentuk menjorong, memiliki 3 sayap dan berwarna putih.

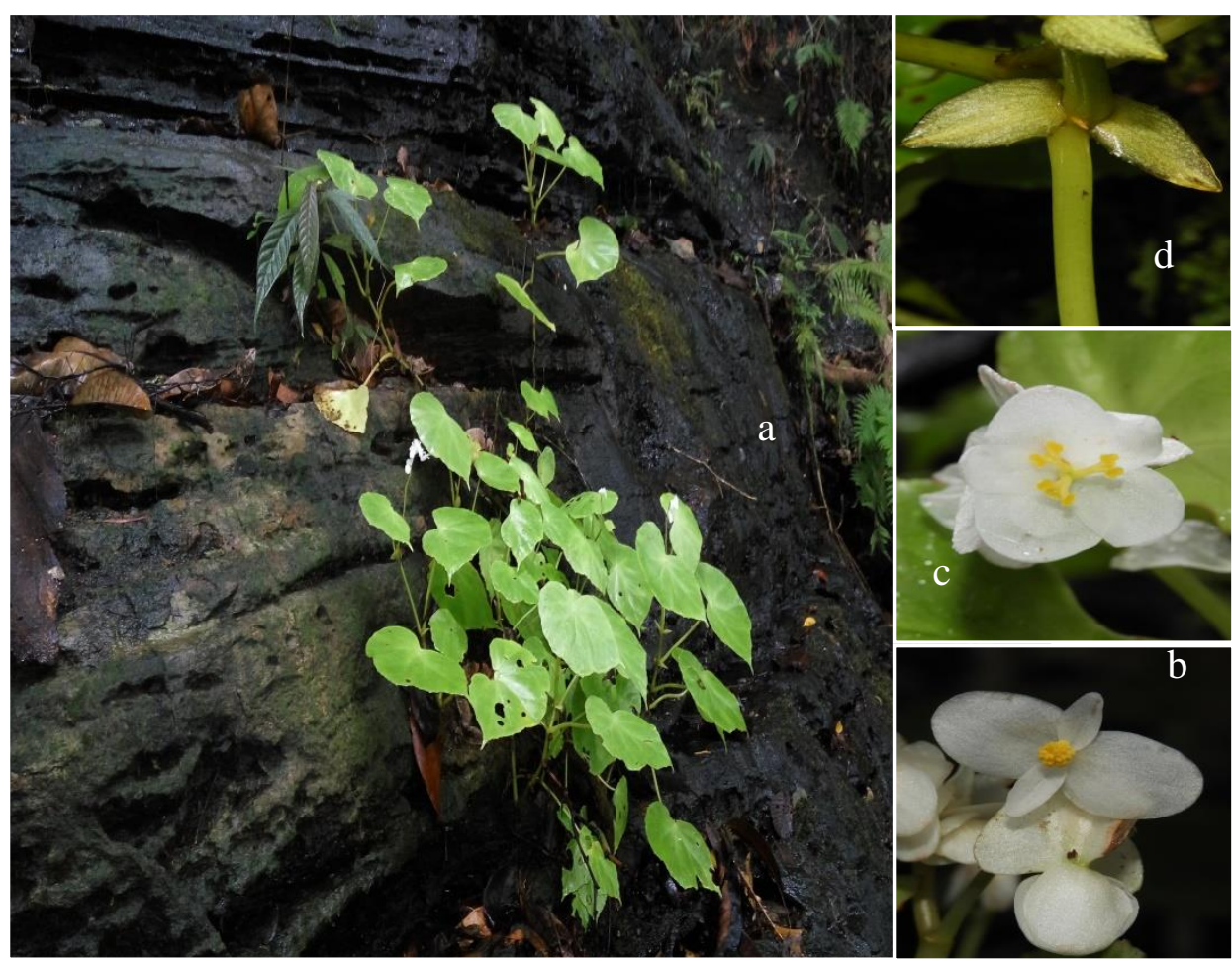

Gambar 8. B. bawangesis Hughes. sp. nov. (in prep). a. Habitat. b. Bunga jantan. c. Bunga betina. d. Batang (B. Hughes Hughes. sp. nov. (in prep). a. Habitat. b. Male flower. c. Female flower. $d$. Stem)

\section{Begonia magnicarpa C.W.Lin \& C.} I Peng.

Berupa terna yang tumbuh di bebatuan. Batang dengan tinggi 10-19 $\mathrm{cm}$ dan berwarna coklat kemerahan. Menurut C.W.Lin, C. I Peng dan, Shin Wen (2017) batang tegak, berwarna kemerahan hingga hijau, setinggi $2 \mathrm{~m}$, antara ruas $4.5-15 \mathrm{~cm}$. Stipul berwarna kehijauan atau kemerahan berbentuk segitiga atau bulat telur. Daun yang membundar telur terbalik (obovate) dengan panjang dengan panjang 10-15 $\mathrm{cm}$ dan lebarnya 6-10 cm, permukaan atas daun berwarna hijau pekat dengan bertotol putih diantara pertulangan daun sedangkan permukaan bawah daun berwarna hijau, tepi daunnya bergerigi, tekstur daun tipis dan licin. Menurut C.W.Lin, C. I Peng dan, Shin Wen (2017) daun memiliki panjang 22-33 cm dan lebar 10-15 cm, pangkal daun tidak rata dan berwarna Hijau pekat. Bunga jantan Begonia memiliki 2 tepal dengan warna putih kemerahan. Bunga betina memiliki 5 tepal dengan warna hijau kemerahan. Menurut C.W.Lin, C. I Peng dan, Shin Wen (2017) bunga jantan berwarna hijau kekuningan dan kemerahan dengan panjang kelopak bunga $7 \mathrm{~mm}$ dan lebar $6 \mathrm{~mm}$. Bunga betina berwarna hijau pucat hingga kemerahan dengan panjang 5-8 mm dan lebar $0.3 \mathrm{~cm}$. Buah yang menjorong dan memiliki 3 sayap berwarna hijau. Menurut C.W.Lin, C. I Peng dan, Shin 
Wen (2017) buah berwarna hijau pucat, memiliki 3 sayap tidak sama besar, berbentuk lonjong dengan panjang 4.5-
Begonia ini tumbuh teresterial dan ditemukan di Batuan Pasir sekitar air terjun Riam Berawat'n.

\section{$5.5 \mathrm{~cm}$ dan lebar 0.6-0.9 $\mathrm{cm}$. Ekologi}

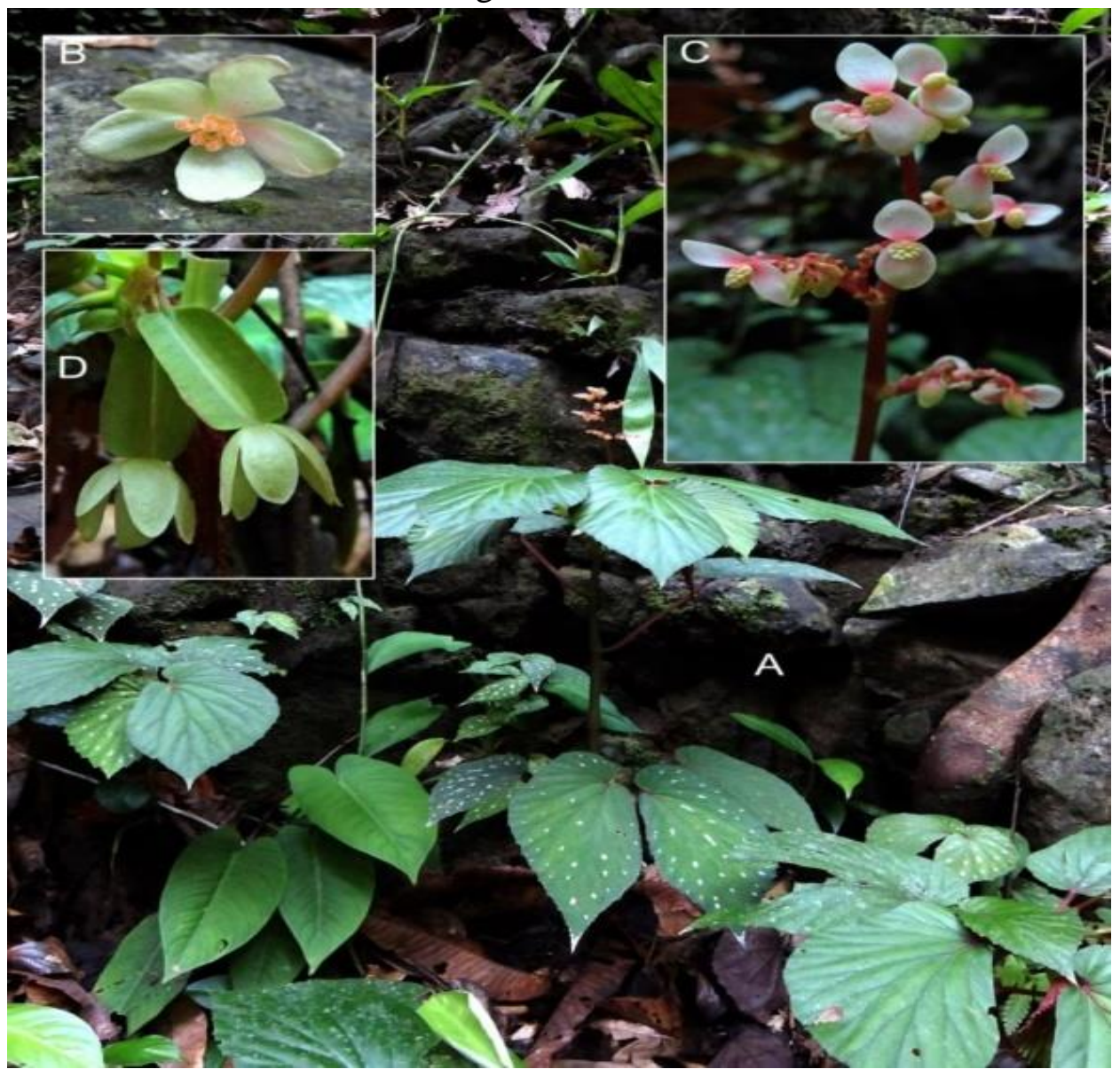

Gambar 9. B. magnicarpa C.W.Lin \& C.-I Peng. a. Habitus. b. Bunga betina c. Pembungaan dan bunga jantan. d. Bunga betina dan ovary. (Photos M. Hughes). (B. magnicarpa C.W.Lin \& C.-I Peng. a. Habitus. $b$. Female flower c. Flowering and male flowers. $d$. Female and ovary flowers. (Photos of M. Hughes)).

\section{KESIMPULAN}

Jenis Begonia yang ditemukan di Kabupaten Bengkayang Kalimantan Barat sebanyak lima spesies. Dari jenis yang ditemukan tidak terdapat Begonia endemik Kalimantan dan jenis yang ditemukan di Batuan Kapur Desa Siding yaitu B. serianensis dan B. stenogyna. Jenis Begonia yang ditemukan di Kawasan Riam Berawat'n Desa Bengkawan yaitu $B$. promethea, $B$. paoana dan B. congesta. Jenis Begonia yang ditemukan di Umbo dan Air Terjun Tikalong yaitu B. paoana, B. calcarea, $B$. propinqua dan $B$. magnicarpa. Spesies Begonia yang ditemukan Gunung Bawang Kecamatan Sungai Betung yaitu B. bawangensis. Ciri khusus pada Begonia terletak pada bunganya yaitu bunga jantan dan bunga betina terpisah namun masih terletak pada satu tumbuhan (monoceus) yang mana bunga jantan memiliki 2 atau 4 tepal dan bunga betina memiliki 5 tepal 
dan memiliki bakal buah pada pangkal bunga.

\section{DAFTAR PUSTAKA}

Achmad, A. 2011. Rahasia Ekosistem Hutan Bukit Kapur. Brilian internasional. Surabaya.

C.W.Lin dan C. I Peng. 2017. Three New Spesies of Begonia (Begoniaceae) from Limestone Hills in Southwestern Sarawak, Borneo. Taiwan. 62 (2): 105-115.

Kiew, R. 2005 Begonias of Peninsular Malaysia. Kota Kinabalu: Natural History Publications, Borneo.

Kiew, R. and S. Julia. 2007. Begonia (Begoniaceae) from limestone hills in the Kuching Division, Sarawak, Borneo, including nine new species. Gard. Bull. Singapore 58(2): 199-232.

Kiew et al. 2015. A Guide to Begonias of Borneo. Kota Kinabalu, Sabah, Malaysia.

Kiew et al. 2018. Taxonomic Status of Begonia Promethea (Sect. Petermania, Begoniaceae) In Borneo. Gardens' Bulletin Singapore. 70(1): 155-161

Marega, Indrayani, Y. Ardian, H. 2016. Keanekaragaman Jenis Tumbuhan Berpotensi Menjadi Tanaman Hias pada Kawasan Hutan Lindung Gunung Bawang Kabupaten Bengkayang. Jurnal Hutan Lestari. 4(4): 534-542.

Nurwidyanto, M. I. Yustiana, M. Widada, S. 2006. Pengaruh Ukuran Butir terhadap Porositas dan Permeabilitas pada Batu Pasir. Berkala Fisika. 9: 191-195.

Rugayah. Retnowati, A. Windradi, F.I. \& Hidayat. 2004. Pedoman Pengumpulan Data
Keanekaragaman Flora. Pusat Penelitian Biologi LIPI. Bogor. 